\title{
PENGARUH DEBT TO ASSETS RATIO (DAR), CURRENT RATIO (CR) DAN CORPORATE GOVERNANCE DALAM MEMPREDIKSI FINANCIAL DISTRESS PADA PERUSAHAAN BUMN SEKTOR NON KEUANGAN YANG TERDAFTAR DI BURSA EFEK INDONESIA
}

\author{
Rochman Marota, Asep Alipudin, Ayursila Maiyarash \\ Fakultas Ekonomi Universitas Pakuan \\ Email: rochmanmarota@yahoo.com
}

\author{
ARTICLE INFO \\ Article History \\ Received 1 October 2018 \\ Revised 31 October 2018 \\ Accepted 1 Nov 2018 \\ JEL Classfication \\ M41, G01, G30, G34 \\ Keywords : \\ Debt to Assets Ratio, \\ Current Ratio, and \\ Corporate Governance
}

\begin{abstract}
ABSTRAK
Kemampuan suatu perusahaan untuk dapat bersaing sangat ditentukan oleh kinerja perusahaan. Perusahaan yang tidak mampu bersaing untuk mempertahankan kinerjanya lambat laun akan tergusur dari lingkungan industrinya dan akan mengalami kebangkrutan. Perusahaan yang terus menunjukan kinerja yang menurun dikhawatirkan akan mengalami kondisi financial distress yang berujung pada kebangkrutan perusahaan. Tujuan penelitian ini adalah untuk menjelaskan pengaruh Debt to Assets Ratio (DAR), Current Ratio (CR), dan Corporate Governance secara parsial dan simultan dalam memprediksi financial distress pada perusahaan BUMN sektor non keuangan yang terdaftar di Bursa Efek Indonesia. Penelitian ini menggunakan data sekunder, metode penarikan sampel menggunakan purposive sampling, metode analisis yang digunakan kuantitatif statistik, analisis data pada penelitian ini yaitu verifikatif dengan metode explanatory survey, analisis regresi linear berganda, dan uji hipotesis. Hasil penelitian ini menunjukan bahwa (1) Secara parsial, Debt to Assets Ratio (DAR) dan Current Ratio (CR) memiliki pengaruh yang signifikan dalam memprediksi financial distress. Sedangkan Corporate governance tidak memiliki pengaruh yang signifikan dalam memprediksi financial distress, (2) Debt to Assets Ratio (DAR), Current Ratio (CR), dan corporate governance secara simultan berpengaruh signifikan dalam memprediksi financial ditress.
\end{abstract}

\section{PENDAHULUAN}

Indonesia merupakan negara

berkembang dengan memiliki badan usaha sendiri yang bergerak dalam berbagai bidang. Badan usaha yang berada langsung dibawah pemerintahan disebut Badan Usaha Milik Negara (BUMN). BUMN berperan dalam menciptakan kesejahteraan bagi masyarakat karena semua ekonomi, potensi sumber daya alam dan faktor-faktor produksi yang ada, dikuasai oleh negara dan dialokasikan pengelolaannya oleh negara kepada organisasi, badan usaha, dan individu untuk kesejahteraan rakyatnya. Diperlukan adanya peningkatan kinerja BUMN agar terciptanya kepercayaan publik (Widyatama, 2017). 
Beberapa tahun terakhir pergerakan ekonomi perusahaan BUMN di Indonesia mengalami penurunan kinerja. Kementerian BUMN mengumumkan, selama periode semester I 2017, ada 24 perusahaan milik negara yang masih merugi. Deputi Bidang Restrukturisasi dan Pengembangan Usaha Kementerian BUMN, Aloysius Kiik Ro mengatakan data ini sedikit lebih baik ketimbang kondisi semester I 2016. Tahun lalu, pada semester I, ada 27 perusahaan negara yang merugi (Idhom, 2017). Perusahaan-perusahaan tersebut yang memiliki laba negatif diantaranya adalah, PT Aneka Tambang Tbk, PT Garuda Indonesia Tbk, PT Indofarma Tbk dan PT Krakatau Steel Tbk,. Hal ini dapat dilihat dari data keuangan di bawah ini:

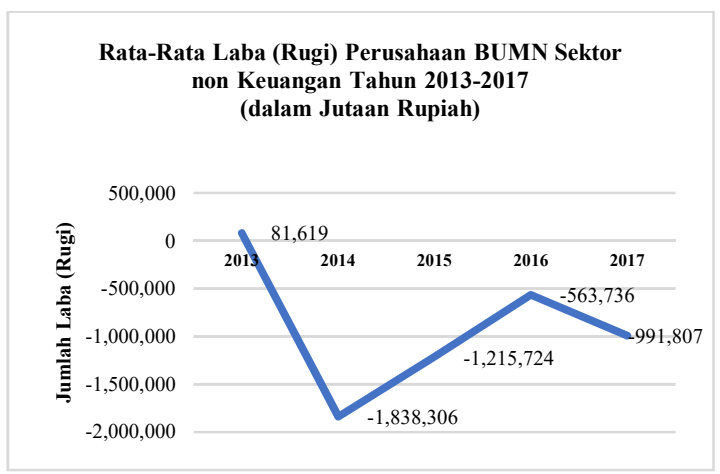

Sumber : www.idx.co.id, 2018

Gambar 1. Rata-Rata Laba (Rugi) Perusahaan BUMN Sektor non Keuangan yang Terdaftar di BEI Tahun 2013-2017

Pada Gambar 1 di atas dapat dilihat bahwa hanya tahun 2013 perusahaanperusahaan BUMN non keuangan di Indonesia mengalami laba, sedangkan pada tahun-tahun berikutnya perusahaan BUMN non keuangan mengalami kerugian. Kerugian terbesar dialami pada tahun 2014 sebesar Rp. 1.838.306. Di tahun 2015-2016 perusahaanperusahaan BUMN non keuangan mulai memperbaiki kinerjanya, namun pada tahun 2017 mengalami peningkatan kerugian. Perusahaan harus semakin berhati-hati dalam menghadapi persaingan agar tidak mengalami kerugian terus-menerus dan terjadi kebangkrutan.

Kebangkrutan merupakan masalah yang harus diwaspadai oleh perusahaan. Menurut Rudianto (2013), kebangkrutan diartikan sebagai kegagalan perusahaan dalam menjalankan operasi untuk mencapai tujuannya. Kegagalan ekonomis berarti bahwa pendapatan perusahaan tidak mampu menutup biaya sendiri. Sedangkan kegagalan keuangan berarti perusahaan tidak dapat memenuhi kewajibannya ketika harus dipenuhi, walaupun total nilai aset melebihi kewajiban totalnya.

Gejala awal terjadinya kebangkrutan ditandai dengan kesulitan keuangan (financial ditress) yang di alami oleh perusahaan. Istilah financial ditress digunakan untuk mencerminkan adanya permasalahan dengan likuiditas yang tidak dapat dijawab atau diatasi tanpa harus melakukan keuangan jangka pendek (tidak mampu membayar kewajiban keuangan pada saat jatuh temponya) yang tidak tepat maka akan menimbulkan permasalahan yang lebih besar yaitu menjadi tidak solvable (jumlah liabilitas lebih besar daripada jumlah aset) dan akhirnya mengalami kebangkrutan (Munawir, 2013). Apabila kondisi financial ditress tidak ditangani dengan tepat maka kebangkrutan atau likuidasi dapat terjadi pada perusahaan tersebut. Indikator kesulitan keuangan perusahaan dapat dilihat dari kegagalan perusahaan dalam menjalankan aktivitas perusahaan untuk menghasilkan laba. Untuk mengatasi dan meminimalisir terjadinya kebangkrutan, perusahaan dapat mengawasi kondisi keuangannya dari segi laporan posisi keungan dan laporan laba rugi yang ada dalam laporan keuangan perusahaan dengan menggunakan teknik-teknik analisis laporan keuangan.

Harahap (2013) menjelaskan analisis laporan keuangan berarti, mengurangi pos-pos laporan keuangan menjadi unit informasi yang lebih dan melihat hubungan yang bersifat signifikan atau mempunyai makna antara satu dengan yang lain baik antara data kualitatif 
maupun data non kualitatif dengan tujuan untuk mengetahui kondisi keuangan lebih dalam yang sangat penting dalam proses menghasilkan keputusan yang tepat.

Rasio leverage dapat digunakan untuk memprediksi financial ditress. Debt to Assets Ratio (DAR) merupakan rasio yang mengukur sejauh mana aset perusahaan dibiayai oleh hutang. Ataupun kemampuan mengukur seberapa besar beban utang yang harus ditanggung perusahaan dalam rangka pemenuhan aset (Hery, 2016).

Rasio likuiditas juga dapat digunakan untuk memprediksi terjadinya financial ditress. Current Ratio (CR) adalah rasio yang mengukur kemampuan perusahaan dalam memenuhi kewajiban atau membayar utang jangka pendeknya yang segera jatuh tempo dengan menggunakan total aset lancar yang tersedia. Dengan kata lain rasio ini dapat digunakan untuk mengukur sampai berapa jauh tingkat kemampuan perusahaan dalam melunasi kewajiban jangka pendeknya yang akan segera jatuh tempo (Hery, 2016).

Untuk mengukur financial ditress tidak hanya dari segi keuangannya saja. Manajemen perusahaan juga merupakan hal yang sangat penting untuk menghasilkan kinerja perusahaan yang baik. Dalam manajemen perusahaan diperlukan tata kelola yang baik (Good Corporate Governance) guna memperoleh hasil yang maksimal. Corporate governance merupakan suatu sistem hubungan yang didefinisikan sebagai struktur dan proses (ICGM, 2014).

Perusahaan Badan Usaha Milik Negara (BUMN) adalah sasaran utama pemerintah Indonesia untuk dapat menerapkan prinsipprinsip tata kelola perusahaan yang baik. Hal tersebut didukung oleh pendapat Kaihatu dalam Novita dkk. (2018), yang menyatakan bahwa BUMN merupakan pelaku utama didalam ekonomi Indonesia. Prinsip Good Corporate governance yang terdapat dalam peraturan perundang-undangan di Indonesia pada UU No.19 Tahun 2003 tentang Badan
Usaha Milik Negara (BUMN). Melalui Peraturan Menteri Negara BUMN Nomor: PER - 01 /MBU/2011 tentang Penerapan Tata Kelola Perusahaan Yang Baik (Good Corporate governance) pada Badan Usaha Milik Negara, menekankan kewajiban bagi BUMN untuk menerapkan Good Corporate governance secara konsisten dan atau menjadikan prinsipprinsip Good Corporate governance sebagai landasan operasionalnya, yang pada dasarnya bertujuan untuk meningkatkan keberhasilan usaha dan akuntabilitas perusahaan guna mewujudkan nilai pemegang saham dalam jangka panjang dengan tetap memperhatikan kepentingan stakeholders lainnya, dan berlandaskan pada peraturan perundangundangan dan nilai-nilai etika (Keputusan Menteri Badan Usaha Milik Negara, 2011).

Tabel 1. Perusahaan Penerima Penghargaan Indonesia Good Corporate governance Award 2017 Kategori Sektor BUMN Go Public

\begin{tabular}{llc}
\hline No & \multicolumn{1}{c}{ Perusahaan } & $\begin{array}{c}\text { Pering } \\
\text { kat }\end{array}$ \\
\hline 1 & PT Antam (Persero), Tbk. & 1 \\
\hline 2 & $\begin{array}{l}\text { PT Garuda Indonesia } \\
\text { (Persero), Tbk. }\end{array}$ & 2 \\
\hline 3 & PT Timah (Persero), Tbk. & 3 \\
\hline 4 & PT Semen Indonesia, Tbk. & 4 \\
\hline 5 & PT Adhi Karya (Persero), Tbk. & 5 \\
\hline 6 & $\begin{array}{l}\text { PT Wijaya Karya (Persero), } \\
\text { Tbk. }\end{array}$ & 6 \\
\hline 7 & PT PGN (Persero), Tbk. & 7 \\
\hline 8 & $\begin{array}{l}\text { PT Kimia Farma (Persero), } \\
\text { Tbk. }\end{array}$ & 8 \\
\hline 9 & $\begin{array}{l}\text { PT Bukit Asam (Persero), } \\
\text { Tbk. }\end{array}$ & 9 \\
\hline 10 & $\begin{array}{l}\text { PT Semen Baturaja (Persero), } \\
\text { Tbk. }\end{array}$ & 10 \\
\hline
\end{tabular}

Sumber: Embu, November 2017

Dari tabel di atas dapat dilihat bahwa PT Aneka Tambang, Tbk berhasil terpilih sebagai BUMN Tbk terbaik, diikuti PT Garuda 
Indonesia, Tbk diperingkat kedua. Perusahaanperusahaan tersebut merupakan perusahaan yang sedang mengalami kerugian dan menjadi sampel penelitian.

Menurut Lizal dalam Wijoyo (2016), salah satu penyebab terjadinya financial ditress adalah Corporate governance model, yaitu ketika perusahaan memiliki susunan aset yang tepat dan struktur yang baik dikelola dengan buruk. Hal ini tentunya sangat bertentangan dengan teori, yang mana dua perusahaan tersebut mengalami kerugian atau financial ditress namun tata kelola perusahaannya dikatakan baik.

Berbagai penelitian telah dilakukan terkait mengenai Debt to Assets Ratio (DAR), Current Ratio (CR) dan Corporate governance dalam memprediksi financial ditress. Hasil penelitian yang dilakukan oleh Ananto, dkk (2017) menunjukkan variabel DAR mempunyai pengaruh yang signifikan terhadap financial ditress, namun hal ini berbeda dengan penelitian Elen dan Juniarti (2013) yang menunjukkan hasil bahwa DAR tidak memiliki pengaruh yang signifikan terhadap financial ditress. Lalu, penelitian yang dilakukan oleh Santosa (2017) menunjukan variabel CR

\section{KAJIAN LITERATUR DAN PENGEMBANGAN HIPOTESIS \\ Debt to Assets Ratio (DAR)}

Menurut Hery (2016), Debt to Assets Ratio (DAR) merupakan rasio yang digunakan untuk mengukur perbandingan antara total utang dengan total aset. Dengan kata lain, rasio ini digunakan untuk mengukur seberapa besar aset perusahaan dibiayai oleh utang atau seberapa besar utang perusahaan berpengaruh terhadap pembiayaan aset. Rasio ini untuk mengukur kemampuan perusahaan dalam menjamin utang-utangnya dengan sejumlah aktiva yang dimilikinya (Wardiyah, 2016).

Berdasarkan hasil pengukuran yang dilakukan, apabila besaran rasio utang terhadap aset adalah tinggi maka hal ini tentu saja akan mengurangi kemampuan mempunyai pengaruh yang signifikan terhadap financial ditress, namun hal ini berbeda dengan penelitian Rahmawati dan Khoiruddin (2017) yang menyatakan bahwa CR tidak memiliki pengaruh yang signifikan terhadap financial ditress. Selain itu, penelitian yang dilakukan oleh Cahyani dan Diantini (2016) menyatakan bahwa Corporate governance berpengaruh signifikan terhadap financial ditress, Sedangkan penelitian Ellen dan Juniarti (2013) menemukan bahwa penerapan GCG tidak berpengaruh signifikan dalam memprediksi financial ditress perusahaan. Hasil serupa juga ditemukan oleh Juniarti dan Natalia (2012) menyatakan bahwa perusahaan yang memiliki GCG score yang tinggi dan memiliki predikat terpercaya memiliki default risk yang rendah. Dengan memperhatikan perbedaan hasil dalam penelitian yang telah disebutkan, peneliti bermaksud untuk mengkaji ulang mengenai Debt to Assets Ratio (DAR), Current Ratio (CR) dan Corporate governance dalam Memprediksi Financial ditress Pada Perusahaan BUMN Sektor non Keuangan yang Terdaftar di Bursa Efek Indonesia Tahun 20132017.

perusahaan untuk memperoleh tambahan pinjaman dari kreditor karena dikhawatirkan bahwa perusahaan tidak mampu melunasi utang-utangnya dengan total aset yang dimilikinya. Rasio yang kecil menunjukan bahwa sedikitnya aset perusahaan yang dibiayai oleh utang (dengan kata lain bahwa sebagian besar aset yang dimiliki perusahaan yang dibiayai oleh modal).

\section{Current Ratio (CR)}

Hery (2016), rasio lancar merupakan rasio yang digunakan untuk mengukur kemampuan perusahaan dalam memenuhi kewajiban jangka pendeknya yang akan segera jatuh tempo dengan menggunakan total aset lancar yang tersedia. Dengan kata lain, rasio lancar ini menggambarkan seberapa besar jumlah ketersediaan aset lancar yang dimiliki 
perusahaan dibandingkan dengan total kewajiban lancar. Oleh sebab itu, rasio lancar dihitung sebagai hasil bagi antara total aset lancar dengan total kewajiban lancar.

Menurut Fahmi dalam Ambarwati (2018), kondisi perusahaan yang memiliki Current Ratio yang baik adalah dianggap sebagai perusahaan yang baik dan bagus, namun jika Current Ratio terlalu tinggi juga dianggap tidak baik karena dapat mengindikasikan adanya masalah seperti jumlah persediaan yang relatif tinggi dibandingkan taksiran tingkat penjualan sehingga tingkat perputaran persediaan rendah dan menunjukan adanya investasi berlebih (over investment) dalam persediaan tersebut atau adanya saldo piutang yang besar tak tertagih.

\section{Corporate governance}

Berdasarkan Peraturan Menteri Negara BUMN Nomor: PER - 01/MBU/2011 (2011, pasal 1), mendefinisikan Tata Kelola Perusahaan sebagai berikut:

"prinsip-prinsip yang mendasari suatu proses dan mekanisme pengelolaan perusahaan berlandaskan peraturan perundang-undangan dan etika berusaha."

Menurut The Indonesian Institute for Corporate governance (IICG) dalam Hamdani (2016), mendefinisikan Good Corporate governance sebagai proses dan struktur yang diterapkan dalam menjalankan perusahaan, dengan tujuan utama meningkatkan nilai pemegang saham dalam jangka panjang dengan tetap memperhatikan kepentingan pihak petaruh lainnya.

Dalam penelitian Alamsyah (2015) untuk menilai Good Corporate governance, dapat menggunakan beberapa unsur Corporate governance yang berasal dari dalam perusahaan dan unsur yang selalu diperlukan dalam perusahaan. Unsur-unsur tersebut diantaranya adalah dewan komisaris, dewan direksi, dan komite audit. Pengukuran tiga unsur tersebut dilakukan berdasarkan jumlah anggota yang bertugas dalam suatu perusahaan yang disebutkan dalam laporan tahunan.

Menurut Hamdani (2016), dewan komisaris sebagai organ perusahaan bertugas dan bertanggung jawab secara kolektif untuk melakukan pengawasan dan memberikan nasihat kepada direksi serta memastikan bahwa perusahaan melaksanakan GCG.

Menurut Hamdani (2016), direksi sebagai organ perusahaan yang bertugas dan bertanggung jawab secara kolegial dalam mengelola perusahaan. Masing-masing anggota direksi dapat melaksanakan tugas dan mengambil keputusan sesuai dengan pembagian tugas dan wewenangnya. Namun, pelaksanaan tugas oleh masing-masing anggota direksi tetap merupakan tanggung jawab bersama.

Ikatan Komite Audit Indonesia (AKAl) mendefinisikan komite audit adalah suatu komite yang bekerja secara profesional dan independen yang dibentuk oleh dewan komisaris dan dengan demikian tugasnya adalah membentuk dan memperkuat fungsi dewan komisaris atau dewan pengawas dalam menjalankan fungsi pengawasan atas proses laporan keuangan, manajemen resiko, pelaksanaan audit, dan implementasi dari Corporate governance di perusahaanperusahaan.

\section{Financial ditress}

Financial ditress merupakan suatu kondisi dimana perusahaan sedang menghadapi masalah kesulitan keuangan. Menurut Fachrudin dalam Hery (2017), kesulitan keuangan dimulai ketika perusahaan tidak dapat memenuhi jadwal pembayaran atau ketika proyeksi arus kas mengindikasikan bahwa perusahaan tersebut akan segera tidak dapat memenuhi kewajibannya.

Financial ditress adalah situasi dimana arus kas operasi perusahaan tidak memadai untuk melunasi kewajiban-kewajiban lancar (seperti hutang dagang atau beban bunga) dan perusahaan terpaksa melakukan tindakan 
perbaikan. Dan kesulitan keuangan adalah masalah likuidasi yang sangat parah yang tidak bisa dipecahkan tanpa perubahan ukuran dari operasi atau struktur perusahaan. Informasi financial ditress ini dapat dijadikan sebagai peringatan dini atas kebangkrutan sehingga manajemen dapat melakukan tindakan secara cepat untuk mencegah masalah sebelum terjadinya kebangkrutan, dimana kebangkrutan suatu perusahaan ditandai dengan financial ditress yaitu keadaan dimana perusahaan lemah dalam menghasilkan laba atau perusahaan cenderung mengalami defisit (Ramdhani dan Lukviarman dalam Ambarsari 2018).

\section{Pengembangan Hipotesis}

Pengaruh Debt to Assets Ratio (DAR) terhadap Financial ditress

Debt to Assets Ratio (DAR) merupakan rasio yang digunakan untuk mengukur perbandingan antara total utang dengan total aset. Dengan kata lain, rasio ini digunakan untuk mengukur seberapa besar aset perusahaan dibiayai oleh utang atau seberapa besar utang perusahaan berpengaruh terhadap pembiayaan aset (Hery, 2016).

Penelitian yang dilakukan oleh Ananto, dkk (2017) dan Fathonah (2016), menunjukkan bahwa Debt to Assets Ratio (DAR) berpengaruh signifikan terhadap kondisi financial ditress. Artinya semakin besar aset perusahaan yang dibiayai oleh utang semakin besar pula kemungkinan terjadinya kondisi financial ditress, akibat semakin besar kewajiban perusahaan untuk membayar utang tersebut. Maka dari itu Debt to Assets Ratio (DAR) memiliki hubungan terhadap financial ditress.

\section{Pengaruh Current Ratio (CR) terhadap Financial ditress}

Setiap perusahaan dalam menjalankan aktivitas atau operasinya sehari-hari selalu membutuhkan modal kerja (working capital). Semakin besar aktiva lancar terhadap kewajiban lancar berarti perusahaan mempunyai modal kerja positif yang menunjukkan semakin besar kemampuan perusahaan untuk membayar hutanghutangnya (semakin likuid). Munawir dalam Ambarsari (2018) mengatakan bahwa adanya modal kerja yang cukup sangat penting bagi suatu perusahaan karena dengan modal kerja yang cukup itu memungkinkan bagi perusahaan untuk beroperasi dengan seekonomis mungkin dan perusahaan tidak mengalami kesulitan atau menghadapi bahaya-bahaya yang mungkin timbul karena adanya krisis atau kekacauan keuangan.

Current Ratio (CR) yang rendah menunjukkan likuiditas jangka pendek yang rendah, sedangkan Current Ratio (CR) yang tinggi menunjukkan kelebihan aktiva lancar yang berarti likuiditas tinggi dan risiko rendah. Semakin besar tingkat likuiditas perusahaan, dalam hal ini aktiva lancarnya, memperlihatkan semakin baik kemampuan perusahaan dalam memenuhi kewajiban jangka pendeknya, sehingga dalam jangka pendek terhindar dari kemungkinan terjadinya probabilitas kebangkrutan (Vatmawati, 2017).

Menurut penelitian yang dilakukan oleh Elen dan Juniarti (2013) menunjukkan hasil bahwa Current Ratio (CR) memiliki pengaruh yang signifikan untuk memprediksi financial ditress pada sebuah perusahaan. Hal ini membuktikan bahwa semakin besar kemampuan perusahaan untuk memenuhi kewajiban jangka pendeknya maka semakin kecil kemungkinan terjadinya financial ditress. Penelitian ini diperkuat oleh penelitian Cahyani, Diantini (2016) yang menunjukkan hasil yang sama. Berdasarkan argumen di atas maka Current Ratio (CR) memiliki hubungan terhadap financial ditress.

\section{Pengaruh Corporate governance terhadap Financial ditress}

Tata kelola perusahaan yang baik dapat didefinisikan sebagai sistem yang mengatur dan mengendalikan perusahaan untuk menciptakan nilai tambah bagi setiap stakeholders (Effendi, 2016). 
Isu Good Corporate governance muncul karena terjadi pemisahan antara kepemilikan dengan pengendalian perusahaan, atau seringkali dikenal dengan istilah masalah keagenan. Permasalahan keagenan dalam hubungannya antara pemilik perusahaan dengan manajer adalah bagaimana sulitnya pemilik dalam memastikan bahwa dana yang ditanamkan tidak diambil alih atau diinvestasikan pada proyek yang tidak menguntungkan sehingga tidak mendatangkan return. Good Corporate governance diperlukan untuk mengurangi masalah keagenan antara pemilik dan manajer serta mengurangi terjadinya asimetri informasi dan financial ditress. Corporate governance biasanya mengacu kepada sekumpulan mekanisme yang mempengaruhi keputusan yang akan diambil oleh manajer ketika ada pemisahan antara kepemilikan dan pengendalian, beberapa pengendalian ini terletak pada fungsi dari dewan direksi, pemegang saham institusional, dan pengendalian dari mekanisme pasar Latcker dalam Fathonah (2016).

Penelitian yang dilakukan oleh Cahyani, Diantini (2016) menunjukkan bahwa Corporate governance berpengaruh signifikan terhadap kondisi financial ditress. Artinya semakin baik tata kelola perusahaan maka kemungkinan tidak akan terjadi kondisi financial ditress. Maka Corporate governance memiliki pengaruh terhadap financial ditress.

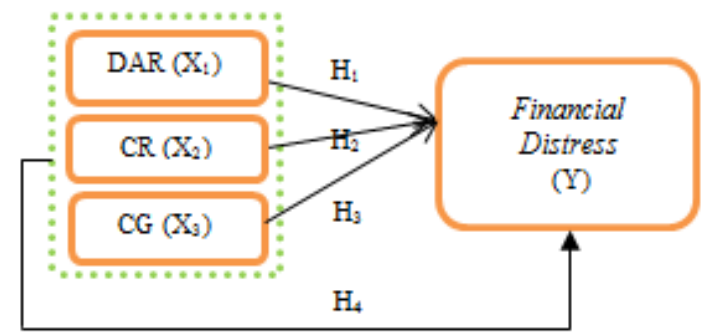

Gambar 2. Kerangka Pemikiran

\section{Hipotesis Penelitian}

Hipotesis 1 : Debt to Assets Ratio (DAR) berpengaruh signifikan terhadap financial ditress

Hipotesis 2 : Current Ratio (CR) berpengaruh signifikan terhadap financial ditress

Hipotesis 3 : Corporate governance berpengaruh signifikan terhadap financial ditress

Hipotesis 4 : Debt to Assets Ratio (DAR), Current Ratio (CR), dan Corporate governance secara simultan berpengaruh signifikan terhadap financial ditress

\section{METODE PENELITIAN}

Jenis penelitian yang digunakan merupakan penelitian verifikatif dengan metode explanatory survey yang bertujuan untuk menguji hipotesis, yang umumnya merupakan penelitian yang menjelaskan fenomena dalam bentuk hubungan antar variabel (2 variabel atau lebih).

Objek penelitian pada penelitian ini adalah variabel-variabel yang meliputi Debt to Assets Ratio (DAR), Current Ratio (CR) dan Corporate governance serta pengaruhnya dalam memprediksi financial ditress. Unit analisis dalam penelitian ini yaitu berupa organisasi, yang merupakan sumber data yang unit analisisnya merupakan respon dari divisi organisasi/ perusahaan. Dalam hal ini unit analisis merupakan divisi organisasi yaitu perusahaan BUMN sektor non keuangan yang terdaftar di BEI tahun 2013-2017. Lokasi penelitian ini adalah perusahaan-perusahaan BUMN sektor non keuangan yang terdaftar di BEI. 
Tabel 2. Operasionalisasi Variabel

\begin{tabular}{llc}
\hline \multicolumn{1}{c}{ Variabel } & \multicolumn{1}{c}{ Indikator } & Ukuran \\
\hline $\begin{array}{l}\text { Debt to Assets Ratio } \\
\text { (DAR) }\end{array}$ & Total liabilitas dan total aset & $\frac{\text { Total liabilitas }}{\text { Total aset }}$ \\
\hline Current Ratio (CR) & Aset lancar dan liabilitas lancar & Rasio \\
& & Liabilitas lancar \\
\hline Corporate governance & Jumlah dewan komisaris & Jumlah seluruh komisaris \\
\cline { 2 - 3 } & Jumlah dewan direksi & Jumlah seluruh dewan direksi \\
\cline { 2 - 3 } & Jumlah komite audit & Jumlah seluruh komite audit \\
\hline Financial ditress & Aset lancar, liabilitas lancar, total aset, laba ditahan, & Rasio $=6,56 \mathrm{X}_{1}+3,26 \mathrm{X}_{2}+6,72 \mathrm{X}_{3}+1,05 \mathrm{X}_{4}$ \\
& EBIT, total ekuitas dan total liabilitas & Rasio \\
\hline
\end{tabular}

Data yang digunakan dalam penelitian ini menggunakan sampel data perusahaan BUMN sektor non keuangan yang terdaftar di BEI tahun 2013-2017. Penarikan sampel pada perusahaan BUMN dengan menggunakan sampel yang dipilih dengan cermat sehingga relavan dengan rancangan penelitian yang disebut dengan metode penarikan sampel purposive sampling. Purposive sampling disebut juga judgement sampling karena peneliti harus mencari sampel yang terdapat wakil-wakil segala lapisan populasi, dengan demikian maka diusahakan agar sampel tersebut memiliki ciri-ciri esensial, strata apa yang harus diwakili, tergantung pada penilaian atau pertimbangan (judgement) dari peneliti. Perusahaan yg dipilih sebagai sampel harus memenuhi kriteria sebagai berikut.

Tabel 3. Kriteria Perusahaan yang Menjadi Sampel

\begin{tabular}{clc}
\hline No & \multicolumn{1}{c}{ Kriteria } & Jumlah \\
\hline 1. & $\begin{array}{l}\text { Perusahaan BUMN yang terdaftar dan menerbitkan laporan keuangan di Bursa } \\
\text { Efek Indonesia periode 2013-2017 }\end{array}$ & 20 \\
\hline 2. & $\begin{array}{l}\text { Perusahaan BUMN yang merupakan perusahaan perbankan dan lembaga } \\
\text { keuangan lainnya. }\end{array}$ & (4) \\
\hline 3. & Perusahaan BUMN yang memiliki laba positif tahun 2013-2017 & $(12)$ \\
\hline & Jumlah Perusahaan & 4 \\
\hline
\end{tabular}

Sumber: www.idx.co.id, 2018

Berdasarkan kriteria yang telah ditetapkan, maka sebanyak 4 perusahaan yang menjadi sampel dalam penelitian ini. Nama-nama perusahaan tersebut dapat dilihat pada tabel di bawah ini:

\begin{tabular}{ccc}
\multicolumn{3}{c}{ Tabel } \\
\hline 4o & Nama Perusahaan yang Menjadi Sampel \\
\hline 1. & ANTM & PT Aneka Tambang Tbk \\
\hline 2. & GIAA & PT Garuda Indonesia Tbk. \\
\hline 3. & INAF & PT Indofarma Tbk. \\
\hline 4. & KRAS & PT Krakatau Steel Tbk. \\
\hline
\end{tabular}

Sumber: www.idx.co.id, 2018 
HASIL PENELITIAN DAN PEMBAHASAN

Uji Asumsi Klasik

Tabel 5. Hasil Uji Normalitas Kolmogrov-Smirnov Test

\begin{tabular}{llr}
\hline & \multicolumn{1}{c}{$\begin{array}{c}\text { Unstandardized } \\
\text { Residual }\end{array}$} \\
\hline$N$ & Mean & 20 \\
Normal Parameters ${ }^{\mathrm{a}, \mathrm{b}}$ & Std. Deviation & .0000000 \\
Most Extreme Differences & Absolute & .51774950 \\
& Positive & .110 \\
& Negative & .092 \\
Test Statistic & .110 \\
Asymp. Sig. (2-tailed) & .110 \\
a. Test distribution is Normal. & $.200^{c, d}$ \\
b. Calculated from data. & \\
c. Lilliefors Significance Correction. & \\
d. This is a lower bound of the true significance. & \\
\hline
\end{tabular}

Berdasarkan tabel 5 di atas menunjukkan bahwa nilai signifikansi yang diperoleh yaitu berada di atas 0,05 , maka nilai residual 0,200 . Karena nilai signifikansi yang dihasilkan tersebut telah normal.

Tabel 6. Hasil Uji Multikolinearitas

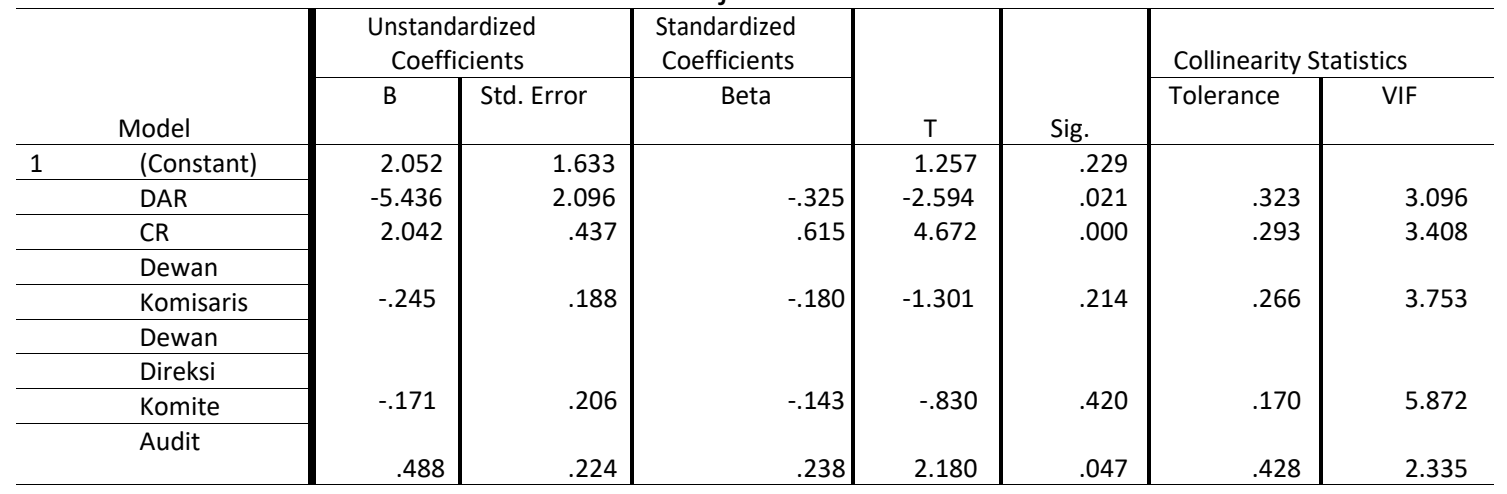

Dari tabel di atas dapat diketahui bahwa nilai tolerance kelima variabel lebih dari 0.10. Dan untuk nilai VIF kelima variabel kurang dari
10. Maka dapat disimpulkan tidak terjadi masalah multikolerasi.

Tabel 7. Hasil Uji Heteroskedastisitas dengan Spearman's rho

\begin{tabular}{|c|c|c|c|c|c|c|c|c|}
\hline & & & DAR & $\mathrm{CR}$ & DK & DD & $\mathrm{KA}$ & $\begin{array}{l}\text { Unstandardiz ed } \\
\text { Residual }\end{array}$ \\
\hline \multirow{10}{*}{$\begin{array}{l}\text { Spearman's } \\
\text { rho }\end{array}$} & \multirow[t]{4}{*}{ DAR } & Correlation & & & & & & \\
\hline & & \multirow{3}{*}{$\begin{array}{l}\text { Coefficient Sig. (2- } \\
\text { tailed) } \\
\mathrm{N}\end{array}$} & 1.000 & $-.708^{* *}$ & .216 & .355 & .193 & .033 \\
\hline & & & . & .000 & .360 & .125 & .416 & .890 \\
\hline & & & 20 & 20 & 20 & 20 & 20 & 20 \\
\hline & \multirow[t]{4}{*}{$\mathrm{CR}$} & Correlation & & & & & & \\
\hline & & \multirow{3}{*}{$\begin{array}{l}\text { Coefficient Sig. (2- } \\
\text { tailed) } \\
\mathrm{N}\end{array}$} & $-.708^{* *}$ & 1.000 & -.353 & -.432 & -.031 & .196 \\
\hline & & & .000 & . & .127 & .057 & .898 & .408 \\
\hline & & & 20 & 20 & 20 & 20 & 20 & 20 \\
\hline & \multirow[t]{2}{*}{ Dewan Komisaris } & Correlation & & & & & & \\
\hline & & Coefficient Sig. (2- & .216 & -.353 & 1.000 & $.671^{* *}$ & $.571^{* *}$ & .005 \\
\hline
\end{tabular}


Rochman Marota: Pengaruh Debt to Assets Ratio (DAR)...

\begin{tabular}{|c|c|c|c|c|c|c|c|}
\hline & & DAR & $\mathrm{CR}$ & DK & DD & KA & $\begin{array}{l}\text { Unstandardiz ed } \\
\text { Residual }\end{array}$ \\
\hline & \multirow{2}{*}{$\begin{array}{l}\text { tailed) } \\
\mathrm{N}\end{array}$} & .360 & .127 & . & .001 & .009 & .982 \\
\hline & & 20 & 20 & 20 & 20 & 20 & 20 \\
\hline \multirow[t]{4}{*}{ Dewan Direksi } & \multirow{4}{*}{$\begin{array}{l}\text { Correlation } \\
\text { Coefficient Sig. (2- } \\
\text { tailed) } \\
\mathrm{N}\end{array}$} & & & & & & \\
\hline & & .355 & -.432 & $.671^{* *}$ & 1.000 & $.756^{* *}$ & .022 \\
\hline & & .125 & .057 & .001 & . & .000 & .926 \\
\hline & & 20 & 20 & 20 & 20 & 20 & 20 \\
\hline \multirow[t]{4}{*}{ Komite Audit } & \multirow{4}{*}{$\begin{array}{l}\text { Coefficient Sig. (2- } \\
\text { tailed) } \\
\mathrm{N}\end{array}$} & & & & & & \\
\hline & & .193 & -.031 & $.571^{* *}$ & $.756^{* *}$ & 1.000 & -.051 \\
\hline & & .416 & .898 & .009 & .000 & . & .830 \\
\hline & & 20 & 20 & 20 & 20 & 20 & 20 \\
\hline Unstandardized & Correlation & & & & & & \\
\hline \multirow[t]{3}{*}{ Residual } & \multirow{3}{*}{$\begin{array}{l}\text { Coefficient Sig. (2- } \\
\text { tailed) } \\
\mathrm{N}\end{array}$} & .033 & .196 & .005 & .022 & -.051 & 1.000 \\
\hline & & .890 & .408 & .982 & .926 & .830 & \\
\hline & & 20 & 20 & 20 & 20 & 20 & 20 \\
\hline
\end{tabular}

Berdasarkan Tabel 7 didapatkan hasil signifikansi dari unstandardized residual kelima variabel independen memiliki hasil nilai
Sig. (2-tailed) lebih dari 0.05 sehingga tidak terjadi masalah heteroskedastisitas.

Tabel 8. Hasil Uji Autokorelasi dengan Durbin Watson

\begin{tabular}{llcccc}
\hline Model & $\mathrm{R}$ & R Square & Adjusted R Square & $\begin{array}{c}\text { Std. Error of the } \\
\text { Estimate }\end{array}$ & Durbin-Watson \\
\hline 1 & $.964^{\mathrm{a}}$ & & .929 & .903 & .60316 \\
\hline
\end{tabular}

Dari tabel di atas dapat diketahui nilai DW (Durbin-Watson) yang dihasilkan dari model regresi adalah 2.121. Sedangkan dari tabel DW dengan signifikansi 0.05 dan jumlah data (n) sebesar 20, dan $\mathrm{k}$ adalah 5 ( $\mathrm{k}$ adalah jumlah variabel independen) diperoleh nilai $d_{\mathrm{L}}=$ sebesar 0.7918 , dan $d_{\cup}$ sebesar 1.9908 . Jadi 4$d_{U}=2.0092,4-d_{\mathrm{L}}=3.2082$. Karena nilai DW (2.121) berada pada daerah antara $d_{\mathrm{L}}$ dan $d_{\mathrm{U}}$, maka hasilnya tidak dapat disimpulkan.

\section{Analisis Regresi Linier Berganda}

Tabel 9. Hasil Uji Koefisien Regresi Linear Berganda

\begin{tabular}{|c|c|c|c|c|c|c|c|}
\hline & & & Coefficients $^{a}$ & & & & \\
\hline & $\begin{array}{r}\text { Unstand } \\
\text { Coeffi }\end{array}$ & $\begin{array}{l}\text { rdized } \\
\text { ients }\end{array}$ & $\begin{array}{l}\text { Standardized } \\
\text { Coefficients }\end{array}$ & & & Collinearity S & stics \\
\hline & $B$ & Std. Error & Beta & & & Tolerance & VIF \\
\hline Model & & & & $\mathrm{t}$ & Sig. & & \\
\hline 1 (Constant) & 2.052 & 1.633 & & 1.257 & .229 & & \\
\hline DAR & -5.436 & 2.096 & -.325 & -2.594 & .021 & .323 & 3.096 \\
\hline CR & 2.042 & .437 & .615 & 4.672 & .000 & .293 & 3.408 \\
\hline Dewan & & & & & & & \\
\hline Komisaris & -.245 & 188 & -.180 & -1.301 & .214 & 266 & 3.753 \\
\hline Dewan & & & & & & & \\
\hline Direksi & -.171 & 206 & -.143 & -.830 & .420 & .170 & 5.872 \\
\hline Komite & & & & & & & \\
\hline Audit & .488 & .224 & .238 & 2.180 & .047 & .428 & 2.335 \\
\hline
\end{tabular}

a. Dependent Variable: Z_Score 
Berikut ini hasil persamaan regresi linear berganda dari data yang terdapat pada tabel 4.13:

$Y=a+b_{1} \cdot X_{1}+b_{2} \cdot X_{2}+b_{3} \cdot X_{3}+b_{4} \cdot X_{4}+b_{5} \cdot X_{5}+e$

$Y=2.052+(-5.436) \mathrm{DAR}+2.042 \mathrm{CR}+(-0.245)$

Dewan Komisaris+(-0.171) Dewan Direksi

+0.488 Komite Audit+e

Interprestasi dari regresi linear berganda tersebut adalah sebagai berikut:

1. Konstanta

Konstanta sebesar 2.052 artinya apabila semua variabel independen yaitu DAR, CR, dewan komisaris, dewan direksi dan komite audit nilainya adalah 0 (nol) maka financial ditress nilainya positif 2.052 .

2. Koefisien Regresi Variabel DAR

Koefisien regresi variabel DAR sebesar 5.436, artinya jika DAR mengalami kenaikan 1 satuan, maka financial ditressakan mengalami kenaikan sebesar 5.436 satuan.

3. Koefisien Regresi Variabel CR
Koefisien regresi variabel CR sebesar 2.042, artinya jika CR mengalami kenaikan 1 satuan, maka financial ditress akan mengalami kenaikan sebesar 2.042 satuan.

4. Koefisien Regresi Variabel Dewan Komisaris Koefisien regresi variabel dewan komisaris sebesar -0.245 , artinya jika DAR mengalami kenaikan 1 satuan, maka financial ditress akan mengalami kenaikan sebesar -0.245 satuan.

5. Koefisien Regresi Variabel Dewan Direksi Koefisien regresi variabel dewan direksi sebesar -0.171, artinya jika CR mengalami kenaikan 1 satuan, maka financial ditresss akan mengalami kenaikan sebesar -0.171 satuan.

6. Koefisien Regresi Variabel Komite Audit Koefisien regresi variabel komite audit sebesar 0.488 , artinya jika CR mengalami kenaikan 1 satuan, maka financial ditress akan mengalami kenaikan sebesar 0.488 satuan.

\section{Uji Hipotesis}

Tabel 10. Hasil Uji Koefisien Regresi Parsial (Uji t)

\begin{tabular}{|c|c|c|c|c|c|c|c|c|}
\hline & \multicolumn{2}{|c|}{$\begin{array}{c}\text { Unstandardized } \\
\text { Coefficients }\end{array}$} & \multirow{3}{*}{$\begin{array}{r}\begin{array}{r}\text { Standardized } \\
\text { Coefficients }\end{array} \\
\text { Beta }\end{array}$} & \multirow[b]{3}{*}{$\mathrm{t}$} & \multirow[b]{3}{*}{ Sig. } & \multicolumn{2}{|c|}{ Collinearity Statistics } \\
\hline & & B & Std. Error & & & & Tolerance & VIF \\
\hline & Model & & & & & & & \\
\hline 1 & (Constant) & 2.052 & 1.633 & & 1.257 & .229 & & \\
\hline & DAR & -5.436 & 2.096 & -.325 & -2.594 & .021 & .323 & 3.096 \\
\hline & CR & 2.042 & 437 & .615 & 4.672 & .000 & .293 & 3.408 \\
\hline & Dewan & & & & & & & \\
\hline & Komisaris & -.245 & 188 & -.180 & -1.301 & .214 & 266 & 3.753 \\
\hline & Dewan & & & & & & & \\
\hline & Direksi & -.171 & .206 & -.143 & -.830 & .420 & 170 & 5.872 \\
\hline & Komite & & & & & & & \\
\hline & Audit & .488 & .224 & .238 & 2.180 & .047 & .428 & 2.335 \\
\hline
\end{tabular}

Berdasarkan signifikansi, jika signifikansi $<0.05$ maka $\mathrm{H}_{1}$ diterima, dan jika signifikansi $>0.05$ maka $\mathrm{H}_{1}$ ditolak. Dilihat dari hasil pada tabel 4.14 terlihat bahwa DAR memiliki nilai signifikansi 0.021 dan thitung sebesar -2.594. Karena signifikansi uji t lebih kecil dari 0.05 $(0.021<0.05)$ dimana nilai $-t_{\text {hitung }}<-t_{\text {tabel }}(-2.594$ $<-2.14479)$ maka $H_{1}$ diterima. Dengan demikian, dapat disimpulkan bahwa DAR secara parsial berpengaruh signifikan dalam memprediksi financial ditress.

Berdasarkan signifikansi, jika signifikansi < 0.05 maka $\mathrm{H}_{2}$ diterima, dan jika signifikansi > 0.05 maka $\mathrm{H}_{2}$ ditolak. Dilihat dari hasil pada tabel 4.14 terlihat bahwa CR memiliki nilai signifikansi 0.000 dan $t_{\text {hitung }}$ sebesar 4.672 . 
Karena signifikansi uji $\mathrm{t}$ lebih kecil dari 0.05 $(0.000<0.05)$ dimana nilai $t_{\text {hitung }}>t_{\text {tabel }}(4.672>$ 2.14479) maka $\mathrm{H}_{2}$ diterima. Dengan demikian, dapat disimpulkan bahwa $\mathrm{CR}$ secara parsial berpengaruh signifikan dalam memprediksi financial ditress.

Berdasarkan signifikansi, jika signifikansi < 0.05 maka $\mathrm{H}_{3}$ diterima, dan jika signifikansi >

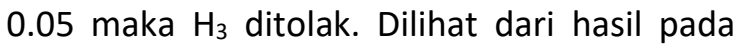
tabel 4.14 terlihat bahwa corporate governace yang diukur dengan dewan komisaris memiliki nilai signifikansi 0.214 dan $t_{\text {hitung }}$ sebesar 1.301. Karena signifikansi uji t lebih besar dari $0.05(0.214>0.05)$ dimana nilai $-t_{\text {hitung }}>-t_{\text {tabel }}(-$ $1.301<-2.14479$. Dengan demikian, dapat disimpulkan bahwa dewan komisaris secara parsial tidak berpengaruh dalam memprediksi financial ditress. Corporate governance yang diukur dengan dewan direksi memiliki nilai signifikansi 0.420 dan $t_{\text {hitung }}$ sebesar -0.830 . Karena signifikansi uji $t$ lebih besar dari 0.05 $(0.420>0.05)$ dimana nilai $-t_{\text {hitung }}>-t_{\text {tabel }}(-$ $0.830<-2.14479)$. Dengan demikian, dapat disimpulkan bahwa dewan direksi secara parsial tidak berpengaruh dalam memprediksi financial ditress. Corporate governance yang diukur dengan komite audit memiliki nilai signifikansi 0.047 dan $t_{\text {hitung }}$ sebesar 2.180. Karena signifikansi uji $\mathrm{t}$ lebih kecil dari 0.05 $(0.047<0.05)$ dimana nilai $t_{\text {hitung }}>t_{\text {tabel }}(2.180$ $>$ 2.14479). Dengan demikian, dapat disimpulkan bahwa komite audit secara parsial berpengaruh signifikan dalam memprediksi financial ditress.

Tabel 11. Hasil Uji Koefisien Regresi Simultan (Uji F)

\begin{tabular}{llrrrrr}
\multicolumn{9}{c}{ ANOVA $^{\mathbf{a}}$} & & \\
\hline & Model & Sum of Squares & Df & Mean Square & F & Sig. \\
\hline 1 & Regression & 66.475 & 5 & 13.295 & 36.545 & $.000^{\text {b }}$ \\
\hline Residual & 5.093 & 14 & .364 & & \\
\hline Total & 71.568 & 19 & & \\
\hline
\end{tabular}

a. Dependent Variable: Z_Score

Predictors: (Constant), Komite Audit, CR, Dewan Komisaris, DAR, Dewan Direksi

Berdasarkan tabel ANOVA pada tabel 11 dapat dilihat bahwa nilai variabel independen $F_{\text {hitung }}$ sebesar 36.545. Dengan menggunakan tingkat keyakinan $95 \% \alpha=5 \%$, df 1 (jumlah variabel -1$)=5$, dan df $2(n-k-1)$ atau 20-5-1 = 14 ( $n$ adalah jumlah kasus dan $k$ adalah jumlah variabel independen), hasil diperoleh untuk $F_{\text {tabel }}$ sebesar 2.96. Tabel ANOVA diatas menunjukan bahwa variabel independen

Tabel 12. Hasil Uji Koefisien Determinasi

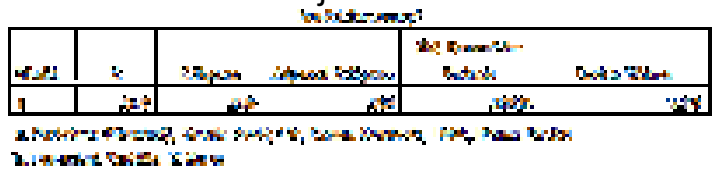

Berdasarkan hasil tabel uji koefisien determinasi terlihat bahwa perolehan $\mathrm{R}$ Square $\left(R^{2}\right)$ adalah sebesar 0.929 atau $92.9 \%$. Nilai tersebut menunjukan bahwa DAR, CR, dewan komisaris, dewan direksi dan komite memiliki nilai signifikansi sebesar 0.000 yang berarti kurang dari 0.05 dan $F_{\text {hitung }}$ sebesar 36.545 diamana nilai $\left(F_{\text {hitung }}>F_{\text {tabel }}\right.$ ) (36.545> 2.96), yang berarti bahwa $\mathrm{H}_{4}$ diterima maka semua variabel independen (DAR, CR, dewan komisaris, dewan direksi, dan komite audit) yang dimasukan dalam model regresi linear berganda berpengaruh secara signifikan terhadap variabel dependen (financial ditress). audit sebagai variabel independen mampu memberikan sumbangan pengaruh terhadap financial ditress sebagai variabel dependen sebesar $92.9 \%$ sedangkan $7.1 \%$ adalah pengaruh faktor lain yang tidak masuk dalam penelitian ini.

\section{Pengaruh Debt to Assets Ratio (DAR) terhadap Financial ditress}

Debt to Assets Ratio (DAR) merupakan rasio untuk mengukur seberapa besar aset perusahaan dibiayai oleh utang atau seberapa 
besar utang perusahaan berpengaruh terhadap pembiayaan aset. Dalam penelitian ini, dengan nilai signifikansi < 0.05 (0.021< 0.05) dan - $t_{\text {hitung }}<-t_{\text {tabel }}(-2.594<-2.14479)$ maka Debt to Assets Ratio (DAR) memiliki pengaruh signifikan terhadap financial ditress.

Penelitian ini sesuai (konsisten) dengan penelitian yang dilakukan oleh Ananto, dkk (2017) menunjukkan variabel DAR mempunyai pengaruh yang signifikan terhadap financial ditress, namun hal ini berbeda dengan penelitian Elen dan Juniarti (2013) yang menunjukkan hasil bahwa DAR tidak memiliki pengaruh yang signifikan terhadap financial ditress.

Berdasarkan hasil analisis diatas, DAR berpengaruh terhadap financial ditress. PT Aneka Tambang Tbk (ANTM) diprediksi memiliki kategori yang sehat dilihat dari nilai Z-score yang diatas 2.6, sehingga PT Aneka Tambang Tbk (ANTM) dalam pengelolaan aset nya tidak banyak dibiayai oleh utang. Ataupun PT Aneka Tambang Tbk (ANTM) dapat melunasi total utangnya dengan aset yang dimilikinya. PT Aneka Tambang Tbk (ANTM) cukup menjaga kinerjanya dalam pengelolaan utangnya. Sedangkan PT Garuda Indonesia Tbk (GIAA) dan PT Krakatau Steel Tbk (KRAS) diprediksi memiliki kategori yang tidak sehat atau mengalami financial ditress karena memiliki nilai Z-score kurang dari 1.1, sehingga PT Garuda Indonesia Tbk (GIAA) dan PT Krakatau Steel Tbk (KRAS) dalam pengelolaan aset nya banyak dibiayai oleh utang. Ataupun PT Garuda Indonesia Tbk (GIAA) dan PT Krakatau Steel Tbk (KRAS) tidak mampu melunasi total utangnya dengan aset yang dimilikinya, sehingga kedua perusahaan tersebut harus memperbaiki pengelolaan atas utangnya. PT Indofarma Tbk (INAF) diprediksi memiliki kategori berada di area abu-abu dilihat dari nilai Z-score yang di atas 1.1 dan dibawah 2.6, sehingga PT Indofarma Tbk (INAF) mengalami ketidak stabilan dalam pengelolaan aset nya yang dibiayai oleh utang. PT Indofarma Tbk (INAF) harus meningkatkan kinerja dalam pengelolaan utangnya agar perusahaan tidak berada dikategori sakit atau financial ditress.

\section{Pengaruh Current Ratio (CR) terhadap Financial ditress}

Current Ratio (CR) merupakan ukuran kemampuan perusahaan untuk membayar kewajiban jangka pendek. Perusahaan yang berada pada posisi likuid berarti dapat membayar kewajiban jangka pendeknya dengan baik pada saat yang bersamaan dapat melakukan kegiatan operasionalnya untuk mencapai laba. Dalam penelitian ini, dengan signifikansi $<0.05(0.000<0.05)$ dan nilai $t_{\text {hitung }}>t_{\text {tabel }}(4.672>2.14479)$ maka Current Ratio (CR) memiliki pengaruh signifikan dalam memprediksi financial ditress.

Penelitian ini sesuai (konsisten) dengan penelitian yang dilakukan oleh Santosa (2017) menunjukan variabel $C R$ mempunyai pengaruh yang signifikan terhadap financial ditress, namun hal ini berbeda dengan penelitian Rahmawati dan Khoiruddin (2017) yang menyatakan bahwa CR tidak memiliki pengaruh yang signifikan terhadap financial ditress.

Berdasarkan hasil analisis diatas, CR berpengaruh terhadap financial ditress. PT Aneka Tambang Tbk (ANTM) diprediksi memiliki kategori yang sehat dilihat dari nilai Z-Score yang diatas 2.6, sehingga PT Aneka Tambang Tbk (ANTM) mampu memenuhi kewajiban jangka pendeknya yang akan segera jatuh tempo dengan menggunakan total aset lancar yang tersedia. PT Aneka Tambang Tbk (ANTM) cukup menjaga kinerjanya dalam pengelolaan utang jangka pendeknya dengan aset lancar yang dimilikinya. Sedangkan PT Garuda Indonesia Tbk (GIAA) dan PT Krakatau Steel Tbk (KRAS) diprediksi memiliki kategori yang tidak sehat atau mengalami financial ditress karena memiliki nilai Z-score kurang dari 1.1, sehingga PT Garuda Indonesia Tbk (GIAA) dan PT Krakatau Steel Tbk (KRAS) tidak mampu memenuhi kewajiban jangka 
pendeknya yang akan segera jatuh tempo dengan menggunakan total aset lancar yang tersedia. Sehingga, kedua perusahaan tersebut harus memperbaiki pengelolaan atas utang jangka pendeknya dengan dengan aset lancar yang dimilikinya. PT Indofarma Tbk (INAF) diprediksi memiliki kategori berada di area abu-abu dilihat dari nilai Z-score yang di atas 1.1 dan dibawah 2.6, sehingga PT Indofarma Tbk (INAF) mengalami ketidak stabilan dalam pengelolaan utang lancarnya dengan aset lancar yang dimilikinya. PT Indofarma Tbk (INAF) belum mampu menjaga kestabilan kinerjanya dalam pengelolaan utang jangka pendeknya. PT Indofarma Tbk (INAF) harus meningkatkan kinerjanya dalam pengelolaan utang jangka pendeknya agar perusahaan tidak berada dikategori sakit atau financial ditress.

\section{Pengaruh Corporate governance terhadap Financial ditress}

Dalam menilai Good Corporate governance, dapat menggunakan beberapa unsur Corporate governance yang berasal dari dalam perusahaan dan unsur yang selalu diperlukan dalam perusahaan. Unsur-unsur tersebut diantaranya adalah dewan komisaris, dewan direksi, dan komite audit.

Dewan komisaris merupakan organ perusahaan yang bertugas dan bertanggung jawab secara kolektif untuk melakukan pengawasan dan memberikan nasihat kepada direksi serta memastikan bahwa perusahaan melaksanakan GCG. Banyaknya jumlah dewan komisaris akan meningkatkan disciplinary control terhadap eksekutif perusahaan. Dalam penelitian ini, dengan signifikansi >0.05 0.214 $>0.05)$ dan nilai $-t_{\text {hitung }}>-t_{\text {tabel }}(-1.301<-$ 2.14479) maka dewan komisaris tidak memiliki pengaruh dalam memprediksi financial ditress. Penelitian ini sesuai (konsisten) dengan Rahmawati, Khoiruddin (2017) dan Ananto, dkk (2017) yang menyatakan bahwa dewan komisaris tidak memiliki pengaruh signifikan dalam memprediksi financial ditress. Namun hal ini berbeda dengan penelitian Yustong
(2018) yang menyatakan bahwa dewan komisaris berpengaruh signifikan dalam memprediksi financial ditress.

Dewan direksi dalam sebuah perusahaan memiliki peran yang sangat penting dalam menentukan keberhasilan perusahaan. keberadaan dewan direksi dalam suatu perusahaan akan menentukan kebijakan atau strategi yang akan diambil baik jangka pendek maupun jangka panjang. Semakin banyaknya anggota dewan direksi, maka dalam perusahaan tersebut semakin banyak pula ahli yang memiliki kemampuan operasional dalam berbagai bidang dan divisi. Dalam penelitian ini, dengan signifikansi $>0.05$ $(0.420>0.05)$ dan nilai $-t_{\text {hitung }}>-t_{\text {tabel }}(-0.830<-$ 2.14479) maka dewan direksi tidak memiliki pengaruh signifikan dalam memprediksi financial ditress. Penelitian ini sesuai (konsisten) dengan penelitian yang dilakukan oleh Ananto, dkk (2017) dan Yustong (2018) yang menyatakan dewan direksi tidak memiliki pengaruh signifikan dalam memprediksi financial ditress. Namun penelitian ini bertentangan dengan penelitian Rahmawati, Khoiruddin (2017) yang menyatakan bahwa dewan direksi memiliki pengaruh yang signifikan dalam memprediksi financial ditress.

Komite audit adalah suatu komite yang bekerja secara profesional dan independen yang dibentuk oleh dewan komisaris dan dengan demikian tugasnya adalah membentuk dan memperkuat fungsi dewan komisaris atau dewan pengawas dalam menjalankan fungsi pengawasan atas proses laporan keuangan, manajemen resiko, pelaksanaan audit, dan implementasi dari Corporate governance di perusahaan-perusahaan. Dalam penelitian ini, dengan signifikansi $0.05(0.047<0.05)$ dan nilai $t_{\text {hitung }}>t_{\text {tabel }}(2.180>2.14479)$ maka komite audit memiliki pengaruh dalam memprediksi financial ditress. Penelitian ini sesuai (konsisten) dengan penelitian Harahap (2017) dan Adityaputra (2017) yang menyatakan bahwa komite audit berpengaruh signifikan dalam memprediksi financial ditress. Namun hal ini bertentangan dengan penelitian 
Ananto, dkk (2017) yang menyatakan bahwa komite audit tidak memiliki pengaruh signifikan dalam memprediksi financial ditress.

Berdasarkan hasil analisis diatas, Corporate governance yang diukur dengan dewan komisaris tidak berpengaruh terhadap financial ditress. Dewan komisaris berfungsi sebagai pengawas dalam perusahaan, namun terkadang para dewan komisaris belum melaksanakan perannya secara maksimal didalam perusahan, sehingga dapat dikatakan dewan komisaris tidak berpengaruh terhadap financial ditress. Corporate governance yang diukur dengan dewan direksi pun tidak berpengaruh terhadap financial ditress. Undang-Undang Nomor 40 Tahun 2007 tentang Perseroan Terbatas pada pasal 92 ayat (4) menyebutkan bahwa Rapat Umum Pemegang Saham (RUPS) menetapkan pembagian tugas dan wewenang pengurusan di antara anggota direksi dalam hal direksi terdiri atas dua anggota direksi atau lebih, sehingga masih ada keterbatasan wewenang direksi. Kondisi suatu perusahaan sebenarnya diketahui oleh direksi, namun keputusan tetap diambil pada Rapat Umum Pemegang Saham (RUPS). Hal inilah yang menyebabkan berapapun jumlah dewan direksi pada suatu perusahaan tidak mempengaruhi terjadinya financial ditress.

Komite audit berpengaruh terhadap financial ditress. PT Aneka Tambang Tbk (ANTM) diprediksi memiliki kategori yang sehat, sehingga jumlah komite audit pada PT Aneka Tambang Tbk (ANTM) dianggap mampu membantu tugas pengawasan untuk meningkatkan pengawasan terhadap laporan keuangan dan mengindikasikan bahwa pengungkapan informasi laporan keuangan ke publik semakin meningkat. Hal ini akan mengurangi tingkat terjadinya fraud pada PT Aneka Tambang Tbk (ANTM) yang mengarah kepada kemungkinan perusahaan mengalami financial ditress. PT Aneka Tambang Tbk (ANTM) cukup menjaga kinerjanya dalam memiliki komite audit yang professional dan handal. Sedangkan PT Garuda Indonesia Tbk (GIAA) dan PT Krakatau Steel Tbk (KRAS) diprediksi memiliki kategori yang tidak sehat atau mengalami financial ditress, sehingga jumlah komite audit yang ada pada PT Garuda Indonesia Tbk (GIAA) dan PT Krakatau Steel Tbk (KRAS) dianggap tidak mampu membantu tugas pengawasan untuk meningkatkan pengawasan atas proses laporan keuangan, manajemen risiko, pelaksanaan audit dan implementasi dari Corporate governance di perusahaannya. Sehingga, kedua perusahaan tersebut harus memperbaiki kinerjanya dengan memiliki komite audit yang dapat membantu fungsi pengawasan. PT Indofarma Tbk (INAF) diprediksi memiliki kategori berada di area abu-abu, jumlah komite audit yang dimilikinya tergolong paling rendah diantara perusahaan yang menjadi sampel lainnya. PT Indofarma Tbk (INAF) harus meningkatkan kinerja atau jumlah dari komite audit agar perusahaan tidak menjadi sakit atau mengalami financial ditress.

\section{Pengaruh Debt to Assets Ratio (DAR), Current Ratio (CR), Corporate governance terhadap Financial ditress}

Berdasarkan hasil penelitian, Debt to Assets Ratio (DAR), Current Ratio (CR) dan Corporate governance yang diukur dengan dewan komisaris, dewan direksi dan komite audit secara bersama-sama (simultan) memiliki pengaruh signifikan dalam memprediksi financial ditress. Debt to Assets Ratio (DAR), Current Ratio (CR) merupakan bagian dari rasio keuangan yang dapat digunakan untuk mengukur kinerja suatu perusahaan. Dewan komisaris, dewan direksi dan komite audit juga dapat digunakan untuk mengukur suatu tata kelola perusahaannya. Analisis rasio dapat digunakan untuk mengevaluasi keadaan financial dimasa lalu dan untuk memproyeksi hasil atau laba dimasa yang akan datang agar tidak financial ditress. Hasil penelitian ini menunjukan bahwa secara bersama-sama (simultan) Debt to Assets Ratio 
(DAR), Current Ratio (CR), dewan komisaris, dewan direksi dan komite audit memiliki pengaruh signifikan dalam memprediksi financial ditress.

\section{PENUTUP}

\section{Simpulan}

Dalam penelitian ini penulis melakukan penelitian mengenai Debt to Assets Ratio (DAR), Current Ratio (CR), dan Corporate governance dalam memprediksi financial ditress pada 4 (empat) perusahaan BUMN sektor non keuangan yang terdaftar di BEI tahun 2013-2017. Berdasarkan penelitian yang telah dilakukan oleh penulis, adapun kesimpulan yang dapat diambil yaitu sebagai berikut:

1. Debt to Assets Ratio (DAR) secara parsial memiliki pengaruh yang signifikan dalam memprediksi financial ditress pada perusahaan BUMN sektor non keuangan yang terdaftar di BEI tahun 2013-2017.

2. Current Ratio (CR) secara parsial memiliki pengaruh yang signifikan dalam memprediksi financial ditress pada perusahaan BUMN sektor non keuangan yang terdaftar di BEI tahun 2013-2017.

3. Corporate governance secara parsial tidak memiliki pengaruh yang signifikan dalam memprediksi financial ditress pada perusahaan BUMN sektor non keuangan yang terdaftar di BEI tahun 2013-2017.

4. Secara simultan menunjukan bahwa Debt to Assets Ratio (DAR), Current Ratio (CR), dan Corporate governance berpengaruh signifikan dalam memprediksi financial ditress pada perusahan-perusahaan BUMN sektor non keuangan yang terdaftar di BEI tahun 2013-2017.

\section{Saran}

Berdasarkan hasil pembahasan mengenai pengaruh Debt to Assets Ratio (DAR), Current Ratio (CR), dan Corporate governance dalam memprediksi financial ditress pada perusahaan BUMN sektor non keuangan yang terdaftar di BEI tahun 2013-
2017, maka saran yang dapat dikemukakan oleh peneliti adalah sebagai berikut:

1. Bagi para pemakai laporan keuangan yang akan mengambil keputusan hendaknya tidak hanya mengandalkan data mengenai Debt to Assets Ratio (DAR), Current Ratio (CR), dewan komisaris, dewan direksi, dan komite audit, tetapi perlu juga memperhatikan faktor-faktor lain dan variabel lain dalam hubungannya dengan financial ditress seperti likuiditas, leverage, dan profitabilitas.

2. Bagi manajemen perusahaan sebaiknya memperhatikan rasio atau variabel yang berpengaruh yaitu Debt to Assets Ratio (DAR), Current Ratio (CR), dewan komisaris, dewan direksi, dan komite audit untuk menghindari kebangkrutan. Bagi perusahaan sebaiknya memprediksi financial ditress sebagai peringatan dini, untuk menghindari kebangkrutan. Sehingga jika perusahaan mengalami financial ditress maka pihak manajemen dapat melakukan berbagai rencana untuk dijadikan strategi peningkatan kualitas perusahaan dimasa yang akan datang.

3. Peneliti selanjutnya dapat menggunakan variabel lain dalam memprediksi financial ditress, karena penelitian ini hanya fokus meneliti faktor intern perusahaan untuk memprediksi financial ditress. Proksi dari Corporate governance dapat diteliti dengan lebih luas seperti kepemilikan manajerial, kepemilikan institutional, dewan komisaris independen dan lain-lain. Variabel lain sebagai faktor ekstern yang dapat digunakan misalnya sisi makro ekonomi, diantaranya tingkat inflasi, suku bunga, nilai tukar mata uang asing, pendapatan bruto nasional dan sebagainya.

\section{REFERENSI}

Ambarsari, I. (2018). Pengaruh Analisis Rasio Keuangan Terhadap Financial ditress Pada Perusahaan Manufaktur yang Terdaftar di BEI. Skripsi. Universitas Pakuan. 
Ananto, Rangga P., dkk. (2017). Pengaruh Good Corporate governance (GCG), Leverage, Profitabilitas, dan Ukuran Perusahaan Terhadap Financial ditress Pada Perusahaan Barang Konsumsi yang Terdaftar di Bursa Efek Indonesia. Jurnal Ekonomi \& Bisnis Dharma Andalas, Vol. 19, No. 1, Januari 2017.

Cahyani, Diah M. dan Diantini, Ayu N., (2016). Peranan Good Corporate governance dalam Memprediksi Financial ditress. Jurnal Manajemen, Strategi Bisnis dan Kewirausahaan .Vol. 10, No. 2, Agustus 2016.

Ellen dan Juniarti. (2013). Penerapan Good Corporate governance, Dampaknya Terhadap Prediksi Financial ditress pada Sektor Aneka Industri dan Barang Konsumsi. Business Accounting Riview. Vol.1, No. 2, 2013.

Embu, Wilfridus S. (2017). Ini daftar perusahaan pemilik tata kelola terbaik se-Indonesia. Merdeka.com, Tersedia di: https://www.merdeka.com/uang/inidaftar-perusahaan-pemilik-tata-kelolaterbaik-se-indonesia.html [Diakses pada 15 Oktober 2018]

Hamdani (2016). Good Corporate governance: Tinjauan Etika dalam Praktik Bisnis. Jakarta: Mitra Wacana Media.

Harahap, S. (2013). Analisis Kritis Atas Laporan Keuangan. Edisi 11. Jakarta: Rajawali Pers.

Hery. (2016). Analisis Laporan Keuangan: Integrated and Comprehensive Edition. Jakarta: Grasindo.
. (2017). Kajian Riset Akuntansi: Mengulas Berbagai Hasil Penelitian Terkini dalam Bidang Akuntansi dan Keuangan. Edisi pertama. Jakarta: PT Grasindo.

Iddhom. (2017). 24 BUMN Masih Merugi Selama Semester I 2017. Tirto.ID, Tersedia di: https://tirto.id/24-bumnmasih-merugi-selama-semester-i-2017cvzn [Diakses 8 September 2018]

Juniarti dan Natalia, L. (2012). Corporate governance Perception Index (CGPI) and Cost of Debt. International Journal of Business and Social Science. Vol. 3 No. 18 (2012).

Rahmawati, D. dan Khoiruddin, M. (2017). Pengaruh Corporate governance dan Kinerja Keuangan dalam Memprediksi Kondisi Financial ditress. Management Analysis Journal. Vol. 6 (1) 2017.

Rudianto. (2013) Akuntansi Manajemen Informasi untuk Pengambilan Keputusan Strategis. Jakarta: Erlangga.

Wardiyah, Mia L. (2017). Analisis Laporan Keuangan. Edisi Pertama (Cetakan kesatu). Bandung: CV Pustaka Setia.

Wijoyo, Agung N. (2016). Menakar Kinerja Perusahaan Pembiayaan: Kesulitan Keuangan Perusahaan Pembiayaan (Financial ditress) (Jilid 2). Jakarta: Universitas Indonesia (UI-Press).

www.idx.co.id. Annually Report. (Diakses pada September 2018. 
